\title{
CELLULOLYTIC ACTIVITY OF TRICHODERMA VIRIDE WITH REGARD TO SELECTED LIGNOCELLULOSIC WASTE MATERIALS
}

\author{
Małgorzata Hawrot-Paw ${ }^{1}$, Monika Izwikow ${ }^{1}$
}

1 Department of Microbiology and Environmental Biotechnology, West Pomeranian University of Szczecin, Słowackiego 17, 71-434 Szczecin, Poland, e-mail: malgorzata.hawrot-paw@zut.edu.pl

Received: 2015.11.10 Accepted: 2015.12.09 Published: 2016.01 .06

\begin{abstract}
The aim of the study was to assess the cellulolytic activity of a strain of Trichoderma viride in the presence of three lignocellulosic substrates, i.e. wheat, barley, and maize straw, in different temperatures $\left(25^{\circ} \mathrm{C}, 30^{\circ} \mathrm{C}\right.$ and $\left.35^{\circ} \mathrm{C}\right)$. Research related to the biosynthesis of enzymes was conducted using the deep method, whereas enzyme activity was assessed on solid media with added carboxymethyl cellulose (CMC). The assessment was based on the activity index (AI) determined for each object of research. The obtained results indicate that $T$. viride produces cellulolytic enzymes, and that their level of activity depends on the type of material introduced into the culture as a lignocellulosic substrate as well as on the temperature. The highest value of AI was found in objects with added maize straw. The optimal temperature for the biosynthesis of cellulolytic enzymes equalled $30^{\circ} \mathrm{C}$.
\end{abstract}

Keywords: cellulolytic activity, Trichoderma viride, lignocellulosic waste materials, bioenergy.

\section{INTRODUCTION}

The world's supply of fossil fuels is gradually depleting, whereas the global need for energy increases continuously. The principle of sustainable development dictates that, in order to provide a better future for subsequent generations, non-renewable fuels should be used rationally, and, at the same time, the obtainability of energy from alternative sources should be improved.

Poland has a considerable potential in terms of renewable energy sources, especially wind and biomass energy [Krawiec 2010]. The latter, when subjected to thermochemical or biochemical conversion in the presence of microorganisms, can provide electricity, heat, and biofuels (Figure 1). Importantly, energy can be obtained not only from biomass as a product, but communal, agricultural, forestry, and industrial waste as well.

The main constituent of plant biomass is lignocellulose, which is made up of three types of polymers: cellulose, hemicellulose, and lignin [Perez et al. 2002, Kumar et al. 2009]. Lignocel- lulosic materials are the most promising feedstock for bioenergy [Perez et al. 2002]. While a range of microorganisms are able to degrade cellulose and hemicellulose by using them as a source of carbon and energy, much fewer microorganisms show the same activity towards lignin [Sanchez 2009]. Among the microorganisms that play an important role in these processes are filamentous fungi, including those from the genus Trichoderma [Miettinen-Oinonen and Suominen 2002, Neethu et al. 2012, Rubeena et al. 2013]. Fungi have two types of exogenous enzymatic systems: the hydrolytic system, responsible for degrading polysaccharides, and the lignolytic system, which determines the decomposition of lignins [Sanchez 2009]. Lignocellulosic materials intended for energy production must undergo initial processing with physical, chemical, or biological methods applied independently or in combination, e.g., thermochemical or biochemical methods [Lim et al. 2012]. Another important consideration that may affect the viability of these materials as an energy source is the pos- 


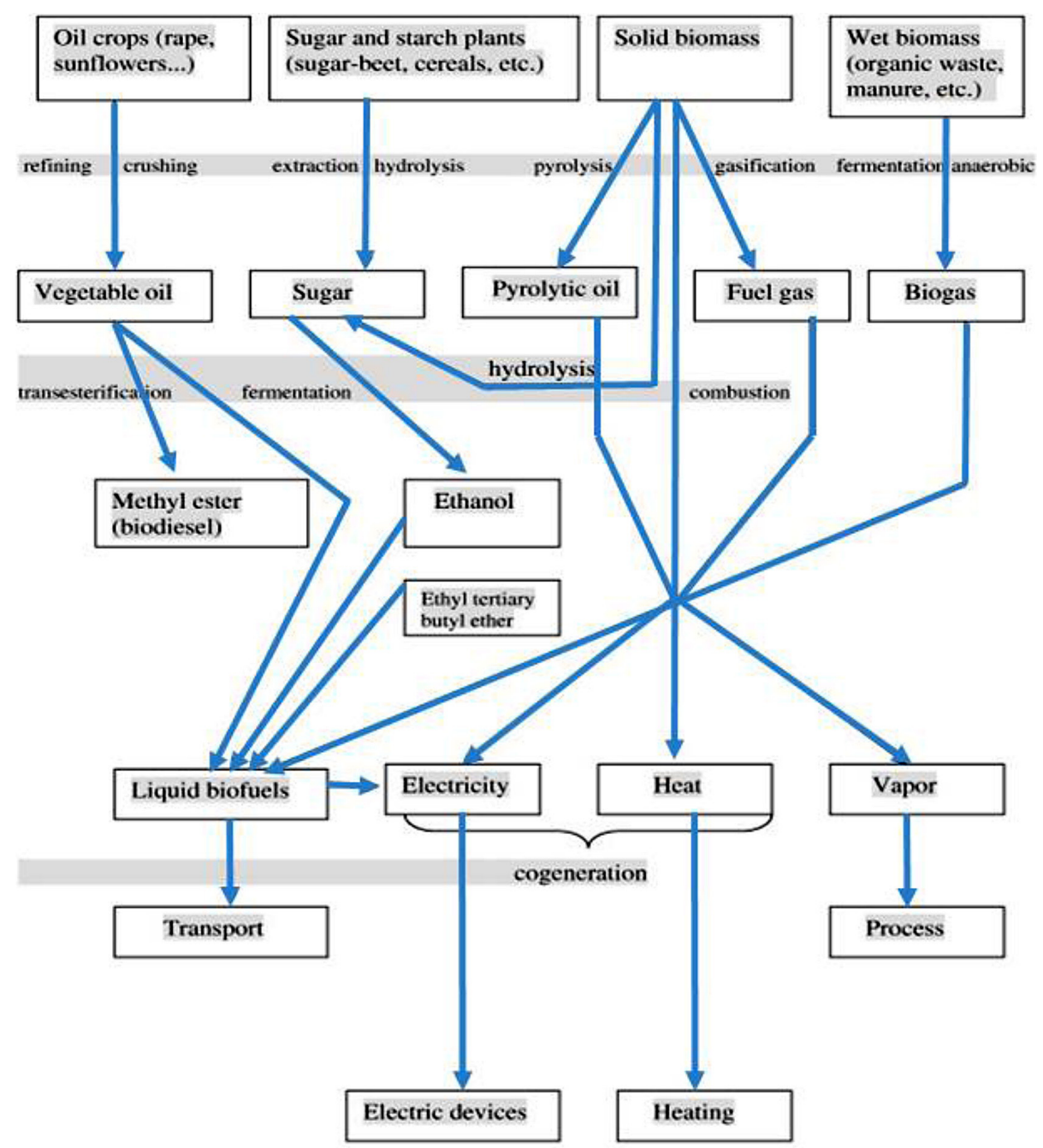

Figure 1. Biomass energy conversion [based on Sanchez 2009]

sibility to provide optimal environmental conditions, adjusted appropriately to the needs of the microorganisms, including the basic ones such as $\mathrm{pH}$ and temperature [Tholudur et al. 1999, Bhattacharya et al. 2014].

The aim of this study was to assess the capability of Trichoderma viride to biosynthesise cellulolytic enzymes with regard to selected lignocellulosic substrates in different temperatures.

\section{MATERIALS AND METHODS}

The researched material constituted a strain from the collection of the Department of Microbiology and Environmental Biotechnology. The production of cellulolytic enzymes was assessed in $250 \mathrm{~cm}^{3}$ Erlenmeyer flasks containing $100 \mathrm{~cm}^{3}$ of liquid modified medium composed of $\left(\mathrm{g} \cdot \mathrm{L}^{-1}\right)$ : urea $0.3 ;\left(\mathrm{NH}_{4}\right)_{2} \mathrm{SO}_{4} 1.4 ; \mathrm{KH}_{2} \mathrm{PO}_{4}$ 2.0; $\mathrm{CaCl}_{2} 0.3 ; \mathrm{MgSO}_{4} 0.3$; yeast extract 0.25; peptone $0.75 \mathrm{~g}$ [Mandels 1975]. Added to the flasks were lignocellulosic substrates weighting $10 \mathrm{~g}$ (respectively wheat straw - WS, barley straw - BS or maize straw - MS), that had been broken down and then ground into fragments with a maximum size of $1-3 \mathrm{~mm}$ in order to increase bioavailability. Also prepared were flasks with a control medium (C) that contained crystalline cellulose instead of lignocellulosic materials.

The media were inoculated by introducing discs with a diameter of $2 \mathrm{~mm}$ cut from a sevenday-old mycelium of $T$. viride (the material was cultivated on the PDA medium at $30^{\circ} \mathrm{C}$ ). Each culture was incubated for seven days at 25, 30 and $35{ }^{\circ} \mathrm{C}$. In order to determine the activity of the produced enzymes, $0.1 \mathrm{~cm}^{3}$ of culture liquid was taken from flasks with the appropriate objects of research and transferred centrally onto a medium solidified on Petri dishes (composition as stated above) with added carboxymethyl cellulose $(1 \% \mathrm{w} / \mathrm{v})$. The experiment was per- 
formed three times. After seven days of incubation at $30^{\circ} \mathrm{C}$, the dishes were flooded with a $1 \%$ aqueous solution of Congo red for 15 minutes and bleached using $1 \mathrm{M} \mathrm{NaCl}$ (20 min). Next, the diameter of the clear zone around the colony was measured (in mm). AI (activity index) was determined based on these measurements by comparing the size of the clear zone to the size of the colony. The results were subjected to statistical analysis using the Statistica ver. 10.0 computer program by StatSoft Poland.

\section{RESULTS AND DISCUSSION}

The annual yields of lignocellulosic biomass in the world is about 220 billion tons [Ren et al. 2009]. Lignocellulosic substrates are renewable, available in large quantities [Bisaria and Ghose 1981] and undergo bioconversion. As many authors indicate, strains belonging to the genus Trichoderma [Khokhar et al. 2012, Neethu et al. 2012, Sartori et al. 2015], may play an important role in these processes, as also confirmed by the presented research. It was found that for the tested strain of Trichoderma viride, the presence of lignocellulosic materials in the growth medium benefitted the production of cellulolytic enzymes (Figure 2.A-C), which is significant taking into account that the materials are waste that can be used to produce biofuels. Also noted were differences in the activity of the strain depending on the applied lignocellulosic substrate. All waste materials contained substances essential for fungal growth and activity, i.e. the source of carbon or nitrogen [Kancelista et al. 2013], but the highest AI was observed in the presence of maize straw.

The average content of cellulose, hemicellulose, and lignin in materials such as those used in this study may amount to, respectively, $29-35 \%, 26-32 \%$, and $16-21 \%$ for wheat straw, $31-34 \%, 24-29 \%$, and $14-15 \%$ for barley straw [Sanchez 2009], and approx. 49\%, $29 \%$, and $7.5 \%$ for maize straw [Song et al. 2014]. Maeda et al. [2011] indicate that cellulolytic enzymes may bind with lignin, causing their effectiveness to drop considerably. Maize straw contains markedly less lignin that the other substrates, which means that the potential level of the reduction of enzymatic activity may be lower in this case.
A. $25^{\circ} \mathrm{C}$

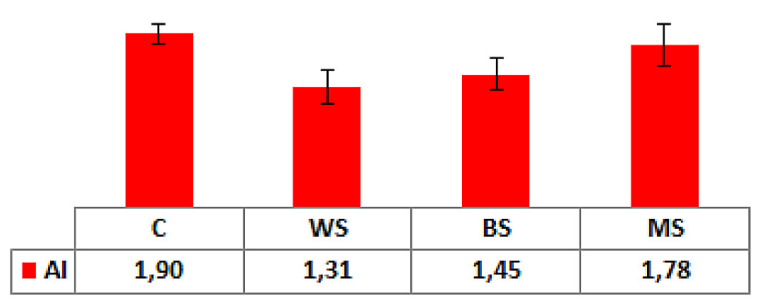

B. $30^{\circ} \mathrm{C}$

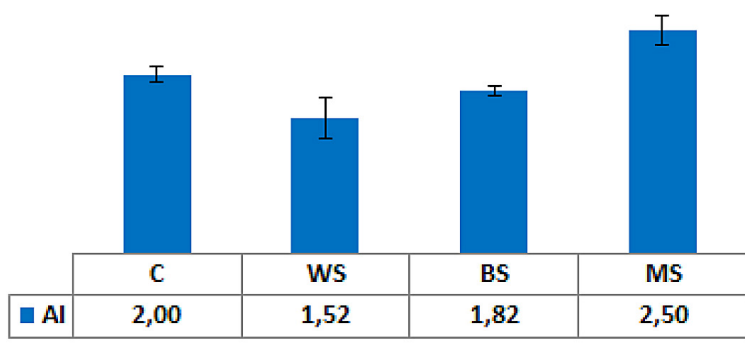

C. $35^{\circ} \mathrm{C}$

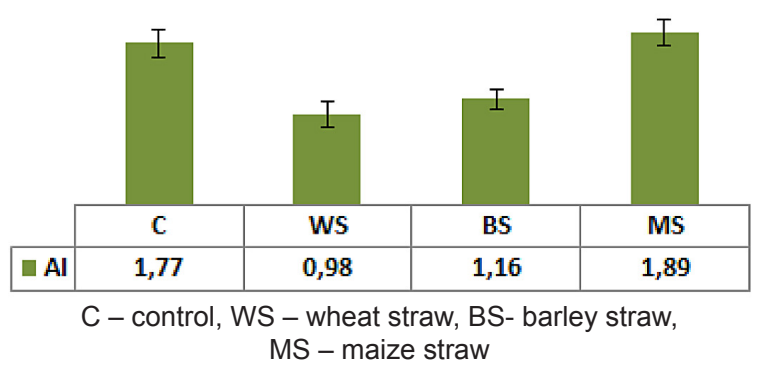

Figure 2. The activity index (AI) in the presence of various lignocellulosic substrates

It is not only the type of substrate, but the environmental conditions as well that have a significant effect on the amount of the produced cellulolytic enzymes [Herculano et al. 2011]. The conducted experiments indicated that the optimal temperature is $30{ }^{\circ} \mathrm{C}$. Similar results were obtained by Bhattacharya et al. [2014], who assessed the relationship between the effectiveness of cellulase production by $T$. viride and such parameters as $\mathrm{pH}$, incubation time, or temperature. In the presented research, an increase in temperature led to an increase in the activity of the strain with regard to maize straw. The observed values of AI were higher than in the other objects of research, including the control. No similar relationship was observed with regard to the other lignocellulosic substrates, in which an increase in temperature over $30{ }^{\circ} \mathrm{C}$ reduced the activity of the strain, which is also confirmed by other authors [Malik et al. 2010]. 


\section{CONCLUSIONS}

The influence of two factors, different lignocellulosic waste materials and temperature, were examined in the current work. The results showed that the lignocellulosic waste substrates introduced into growth media induced the biosynthesis of cellulolytic enzymes by the strain of Trichoderma viride. Cellulolytic activity varied depending on the type of substrate (maize straw $>$ barley straw $>$ wheat straw). The optimal temperature for the biosynthesis of extracellular cellulolytic enzymes is $30{ }^{\circ} \mathrm{C}$, regardless of the type of the lignocellulosic substrate.

\section{REFERENCES}

1. Bhattacharya S., Das A., Patnaik A., Bokade P., Rajan S.S., 2014. Submerged fermentation and characterization of carboxymethyl cellulase from a rhizospheric isolate of Trichoderma viride associated with Azadirachta indica. J. Sci. Ind. Res., 73, 225-230.

2. Bisaria V.S., Ghose T.K., 1981. Biodegradation of cellulosic materials: Substrates, microorganisms, enzymes and products. Enzyme Microbial Technol., 3, 90-104.

3. Herculano P.N., Porto T.S., Moreira K.A., Pinto G.A., Souza-Motta C.M., Porto A.L., 2011. Cellulase production by Aspergillus japonicus URM5620 using waste from castor bean (Ricinus communis L. ) under solid state fermentation. Appl. Biochem. Biotechnol., 165(3-4), 1057-1067.

4. Kancelista A., Tril U., Stempniewicz R., Piegza M., Szczech M., Witkowska D., 2013. Application of lignocellulosic waste materials for the production and stabilization of Trichoderma biomass. Pol. J. Environ. Stud., 22(4), 1083-1090.

5. Khokhar I., Haider M.S., Mushtaq S., Mukhtar I., 2012. Isolation and screening of highly cellulolytic filamentous fungi. J. Appl. Sci. Environ. Manage., 16(3), 223-226.

6. Krawiec F. (red.), 2010. Odnawialne źródła energii w świetle globalnego kryzysu energetycznego. Wybrane problemy. Diffin, Warszawa.

7. Kumar P., Barret D.M., Delwiche M.J., Stroeve P., 2009. Methods for pretreatment of lignocellulosic biomass for efficient hydrolysis and biofuel production. Ind. Eng. Chem. Res., 48(8), 3713-3729.

8. Lim J.S., Abdul Manan Z., Wan Alwi S.R., Hashim H., 2012. A review on utilisation of biomass from rice industry as a source of renewable energy. Renew. Sust. Energ. Rev., 16(5), 3084-3094.
9. Maeda R.N., Serpa V.I., Rocha V.A.L., Mesquita R.A.A., Santa Anna L.M.M., Machado de Castro A., Driemeier C.E., Pereira Jr. N., Polikarpov I., 2011. Enzymatic hydrolysis of pretreated sugar cane bagasse using Penicillium funiculosum and Trichoderma harzianum cellulases. Proc. Biochem., 46, 1196-1201.

10. Malik S.K., Mukhtar H., Farooqi A.A., Haq I., 2010.Optimization of process parameters for the biosynthesis of cellulases by Trichoderma viride. Pak. J. Bot., 42, 4243-4251.

11. Mandels M., 1975. Microbial Sources of cellulase. Biotechnol. Bioeng. Symp., 5, 81-105.

12. Miettinen-Oinonen A., Suominen P., 2002. Enhanced production of Trichoderma reesei endoglucanases and use of the new cellulase preparations in producing the stonewashed effect on denim fabric. Appl. Environ. Microbiol., 68(8), 3956-3964.

13. Neethu K., Rubeena M., Sajith S., Sreedevi S., Priji P., Unni K.N., Sarath Josh M.K., Jisha V.N., Pradeep S., Benjamin S., 2012. A novel strain of Trichoderma viride shows complete lignocellulolytic activities Adv. Biosc. Biotechnol., 3, 1160-1166.

14. Perez J., Munoz-Dorado J., De-la-Rubia T., Martinez J., 2002. Biodegradation and biological treatments of cellulose, hemicelluloses and lignin: an overview. Int. Microbiol., 5, 53-63.

15. Ren N.Q., Wang A.J., Cao G.L., Xu J.F., Gao L.F., 2009. Bioconversion of lignocellulosic biomass is hydrogen: Potential and challenges. Biotechnol. Advan., 27, 1051-1060.

16. Rubeena M., Neethu K., Sajith S., Sreedevi S., Priji P., Unni K.N., Sarath Josh M.K., Jisha V.N., Pradeep S., Benjamin S., 2013. Lignocellulolytic activities of a novel strain of Trichoderma harzianum. Adv. Biosc. Biotechnol., 4, 214-221.

17. Sanchez C., 2009. Lignocellulosic residues: Biodegradation and bioconversion by fungi. Biotechnol. Adv., 27, 185-194.

18. Sartori T., Tibolla H., Prigol E., Colla L.M., Vieira Costa J.A., Bertolin T.E., 2015. Enzymatic saccharification of lignocellulosic residues by cellulases obtained from solid state fermentation using Trichoderma viride. BioMed Research International, volume 2015, article ID 342716, 9 pages.

19. Song Z., Yang G, Liu X., Yan Z., Yuan Y., Liao Y., 2014. Comparison of seven chemical pretreatments of corn straw for improving methane yield by anaerobic digestion. PLoS ONE, 9(4), e93801, doi: 10.1371/journal.pone.0093801.

20. Tholudur A., Ramirez W.F., McMillan J.D., 1999. Mathematical modeling and optimization of cellulose protein production using Trichoderma reseei RL-P37. Biotechnol. Bioeng., 66, 1-16. 